\title{
TINJAUAN YURIDIS TERHADAP PELAKU USAHA TV KABEL MENDIRIKAN USAHA PADA SARANA FASILITAS UMUM DI KOTA SAMARINDA
}

\author{
Oleh : ${ }^{1}$ Eni Rahmawati dan ${ }^{2}$ Eka Wati
}

${ }^{1}$ Fakultas Hukum Universitas 17 Agustus 1945 Samarinda

${ }^{2}$ Dosen Fakultas Hukum Universitas 17 Agustus 1945 Samarinda

\begin{abstract}
This research was conducted at Samarinda City, East Kalimantan Province, Indonesia. This study aims to determine the regulation and legal liability of cable TV business operators who establish businesses in public facilities in Samarinda City. The method that used in this research is a normative legal method that is studying document studies, using various legal materials such as statutory regulations, non-legal materials and in the form of opinions from scholars. The legal material in this study is sourced from primary legal materials, secondary legal materials, and nonlegal materials.

From the results of this study it can be concluded that the legal arrangements for businesses that set up cable TV businesses in public facilities in Samarinda City are contained in Law No.30 of 2009 concerning Electricity Article 48 Paragraph (1). The legal responsibility of cable TV business operators who establish businesses in public facilities in Samarinda against the Samarinda city government is that if an adverse incident occurs that results in pollution and / or environmental damage is considered an illegal act. To overcome various legal issues regarding cable TV business operators, the Samarinda City Regional Government should make a regional regulation specifically regulating the supervision of Cable TV business licensing in Samarinda City because with the regional regulation it is expected to minimize the number of violations of the law, and should Cable TV business operators no longer use electricity network supporting poles which are public facilities owned by the city government, it is far better if cable cable business operators are planted on the ground level, so as to minimize the existence of electrical zippers,
\end{abstract}


fires due to short electrical current and do not disturb the aesthetic of this city.

Keywords: Cable TV Operators, Public Facilities, Legal Arrangements, Legal Liability

\begin{abstract}
ABSTRAK
Penelitian ini dilakukan di Kota Samarinda, Provinsi Kalimantan Timur, Indonesia. Penelitian ini bertujuan untuk mengetahui pengaturan dan pertanggungjawaban hukum pelaku usaha TV Kabel yang mendirikan usaha pada sarana fasilitas umum di Kota Samarinda. Metode yang digunakan pada penelitian ini adalah metode hukum normatif yaitu mengkaji studi dokumen, dengan menggunakan berbagai bahan hukum seperti peraturan perundang-undangan, bahan non hukum dan berupa pendapat dari para sarjana. Bahan hukum dalam penelitian ini bersumber pada bahan hukum primer, bahan hukum sekunder, dan bahan non hukum.

Dari hasil penelitian dapat disimpulkan bahwa pengaturan hukum bagi pelaku usaha yang mendirikan usaha TV kabel di fasilitas sarana umum di Kota Samarinda terdapat pada Undang-Undang No.30 Tahun 2009 tentang Ketenagalistrikan Pasal 48 Ayat (1). Pertanggung jawaban hukum pelaku usaha TV Kabel yang mendirikan usaha pada sarana fasilitas umum di kota Samarinda terhadap pemerintah Kota Samarinda ialah jika terjadi insiden merugikan yang mengakibatkan pencemaran dan/atau kerusakan lingkungan dianggap sebagai perbuatan melawan hukum. Untuk mengatasi berbagai permasalahan hukum mengenai pelaku usaha TV kabel, maka sebaiknya Pemerintah Daerah Kota Samarinda harus membuat peraturan daerah yang secara spesifik mengatur tentang pengawasan terhadap perizinan usaha TV Kabel di Kota Samarinda karena dengan adanya peraturan daerah tersebut diharapkan dapat meminimalisir jumlah pelanggaran hukum, dan sebaiknya pelaku usaha TV Kabel sudah tidak menggunakan tiang penyangga jaringan listrik yang merupakan sarana fasilitas umum milik pemerintah kota, jauh lebih baik apabila kabel pada pelaku usaha TV Kabel ditanam pada permukaan tanah, agar meminimalisir adanya konsleting listrik, kebakaran akibat arus pendek listrik dan tidak mengganggu estetika kota.
\end{abstract}


Kata Kunci: Pelaku Usaha TV Kabel, Fasilitas Umum, Pengaturan Hukum

Pertanggungjawaban Hukum

\section{PENDAHULUAN}

\section{A. Latar Belakang}

Televisi dapat disingkat TV merupakan salah satu media telekomunikasi yang hampir dinikmati oleh seluruh masyarakat Indonesia, khususnya masyarakat Kota Samarinda. Konsumennya pun tidak memandang usia dari balita hingga lansia. Maka dari itu, seluruh saluran televisi (channel TV) dari dalam negeri ataupun dari mancanegara berlomba-lomba menayangkan siaran yang edukatif, kreatif dan inovatif. TV Kabel adalah sistem penyiaran acara televisi lewat isyarat frekuensi radio yang ditransmisikan melalui serat optik yang tetap atau kabel coaxial dan bukan lewat udara seperti siaran televisi biasa yang harus ditangkap antena (over-the air). TV kabel memiliki kualitas gambar lebih tinggi serta kemungkinan sinyal terputus karena angin atau petir sangat kecil bahkan dapat dikatakan tidak ada.

Besarnya peluang yang menghasilkan keuntungan membuat banyaknya pengusaha TV Kabel yang mendirikan usaha dalam penyelenggaraan penyiaran melalui media kabel dengan memanfaatkan sarana fasilitas umum, seperti melintangkan kabel tersebut serta menggunakan penyangga jaringan listrik yang dimiliki perusahaan listrik negara (PLN) yang merupakan sarana fasilitas umum. Kenyataannya, banyak pihak menggunakan tiang penyangga tidak memiliki izin, bahkan pemasangan kabel tidak sesuai dengan standar instalasi dan keamanan salah satunya ialah pelaku usaha TV Kabel. Maraknya usaha TV Kabel di Samarinda menyebabkan tiang penyangga milik PT. PLN (Persero) yang merupakan sarana fasilitas umum menjadi sangat berantakan dan membahayakan warga sekitar. Akibatnya, timbul rasa ketakutan masyarat tinggal disekitar tiang penyangga yang telah melanggar Hak Asasi Manusia atas rasa aman dan nyaman. Undang- Undang Dasar tahun 1945 sebagai norma hukum tertinggi telah memuat pasal- pasal yang menjamin perlindungan, pemajuan, penegakkan, dan pemenuhan Hak Asasi Manusia, karena letaknya dalam konstitusi maka ketentuan- ketentuan mengenai Hak Asasi Manusia harus dihormati dan dijamin pelaksanaanya oleh negara maupun kelompok individu. 
Pentingnya pengurusan izin dalam setiap mengawali kegiatan usaha untuk mendapatkan manfaat dari hak yang telah dilindungi oleh hukum. Izin gangguan yang biasa disebut juga Hinderordonnantie (HO) adalah pemberian izin tempat usaha atau kegiatan kepada orang pribadi atau badan di lokasi tertentu yang dapat menimbulkan bahaya dan gangguan. Subyek izin gangguan ialah orang pribadi atau badan yang memperoleh izin tempat usaha. Dasar hukum izin ini adalah UndangUndang Republik Indonesia Nomor 28 Tahun 2009 Tentang Pajak Daerah dan Retribusi Daerah. Selain itu, masih ada Peraturan Daerah Kabupaten/ Kota yang mengatur secara rinci tentang Retribusi Izin Gangguan. Bahkan pada kabupaten tertentu ada yang menerapkan rumus untuk nenentukan besar biaya retribusi ini. Retribusi ini merupakan pembayaran atas pemberian izin tempat usaha sebagai pribadi atau badan usaha di lokasi tertentu yang menimbulkan bahaya, kerugian dan gangguan. Ini dimaksudkan untuk pembinaan, pengaturan, pengendalian dan pengawasan atas kegiatan pemanfaatan ruang, penggunaan sumber daya alam, barang, prasarana sarana atau fasilitas tertentu guna melindungi kepentingan umum dan menjaga kelestarian lingkungan.

Penertiban pemerintah terhadap pelaku usaha adalah unsur penting agar tidak terjadi keresahan bagi masyarakat yang bertetangga atau berbatasan langsung maupun tidak langsung dengan pelaku usaha yang bisa jadi kegiatan usaha tersebut menimbulkan polusi udara, polusi air, polusi sosial dan sebagainya. Tujuannya tiada lain hal untuk melancarkan penyelenggaraan pemerintahan atau pelayanan kepada masyarakat, dan memberikan kepastian hukum demi mencegah terjadinya stagnasi bagi kemanfaatan dan kepentingan umum. Pembentukan peraturan perundangundangan di Indonesia masih memerlukan perhatian khusus dan kesungguhan karena semakin lama diabaikan, akan semakin rumit. Kerumitan tersebut semakin besar dengan perkembangan dunia yang semakin cepat dan Indonesia sebagai bagian dari dunia, tidak dapat melepaskan diri dari hal tersebut.

\section{B. Rumusan Masalah}

1. Bagaimana pengaturan hukum terhadap pelaku usaha TV Kabel yang mendirikan usaha pada sarana fasilitas umum di kota Samarinda ?

2. Bagaimana pertanggungjawaban hukum pelaku usaha TV Kabel yang mendirikan usaha pada sarana fasilitas umum di kota Samarinda 
terhadap pemerintah kota Samarinda jika terjadi insiden yang merugikan?

\section{Tujuan Penelitian}

Tujuan penelitian ini untuk mengetahui pengaturan hukum bagi pelaku usaha TV Kabel yang mendirikan usaha pada sarana fasilitas umum di kota Samarinda, karena sarana fasilitas umum merupakan sarana yang diperuntukkan untuk umum dan bukan untuk dikuasai orang atau badan usaha dalam melakukan kegiatan komersil, dan untuk mengetahui pertanggungjawaban hukum pelaku usaha TV Kabel yang mendirikan usaha sarana fasilitas umum di kota Samarinda terhadap pemerintah kota Samarinda jika terjadi insiden yang merugikan, karena sarana fasilitas umum diperuntukkan guna kepentingan umum dan bukannya untuk kegiatan komersil perorangan yang berdampak negatif terhadap masyarakat disekitarnya.

\section{Manfaat Penelitian}

Hasil penelitian ini diharapkan dapat menjadi:

1) Masukan bagi Pemerintah Kota Samarinda dalam mengatasi problematika pelaku usaha TV kabel yang mendirikan usaha pada fasilitas umum.

2) Bahan informan bagi Pemerintah Kota Samarinda serta instansiintansi terkait dalam pengaturan dan pertanggungjawaban pelaku usaha TV Kabel.

3) Meningkatkan pengetahuan dan sebagai bahan literasi bagi peneliti dan masyarakat pada umumnya sebagai tambahan informasi mengenai Pelaku Usaha TV Kabel.

\section{KERANGKA DASAR TEORI}

\section{A. Definisi Pelaku Usaha}

Pengertian pelaku usaha menurut Pasal 1 ayat (3) Undang-undang Nomor 8 Tahun 1999 dan Pasal 1 butir 3 Keputusan Menteri Perindustrian dan Perdagangan Nomor 350/MPP/Kep/12/2001 "pelaku usaha adalah setiap perorangan atau badan hukum yang didirikan dan berkedudukan atau melakukan kegiatan dalam wilayah hukum Negara Republik Indonesia, baik sendiri maupun bersama-sama melalui perjanjian menyelenggarakan kegiatan usaha dalam berbagai bidang ekonomi”. 
Definisi Pelaku usaha yang diberikan oleh Pasal 1 butir 3 Undangundang Perlindungan konsumen tersebut, yang termasuk dalam pelaku usaha adalah perusahaan, korporasi, badan usaha milik Negara, koperasi, importer, pedagang, distributor dan lain-lain. Menurut definisi tersebut Undang-undang Perlindungan konsumen berlaku bagi pelaku usaha ekonomi kuat, maupun bagi pelaku usaha ekonomi lemah. Pelaku usaha dalam Undang-undang perlindungan konsumen juga tidak terbatas pada pelaku usaha perorangan yang berkewarganegaraan Indonesia atau badan hukum Indonesia, tetapi juga pelaku usaha perorangan yang bukan berwarganegara Indonesia, atau pelaku badan hukum asing, sepanjang mereka itu melakukan kegiatan dalam wilayah hukum Indonesia negara Republik Indonesia.

Undang Undang No. 8 Tahun 1999 tentang Perlindungan Konsumen memuat defenisi mengenai hukum perlindungan konsumen yaitu sebagai "segala upaya yang menjamin adanya kepastian hukum untuk memberikan perlindungan konsumen". Para konsumen merupakan golongan yang rentan dieksploitasi oleh pelaku usaha. Perlindungan konsumen berasaskan manfaat keadilan, keseimbangan. keamanan dan keselamatan konsumen serta kepastian hukum. Dalam penjelasan pasal 2 undang-undang perlindungan konsumen disebutkan bahwa perlindungan konsumen diselenggarakan sebagai usaha bersama berdasarkan 5 (lima) asas yang relevan dalam pembangunan nasional.

Dilihat dari pengertian diatas, terdapat 4 (empat) unsur yang terkandung dalam pengertian pelaku usaha yaitu:

1. Setiap orang perseorangan atau badan usaha. Yang termasuk badan usaha menurut pengertian ini adalah badan usaha yang berbentuk badan hokum dan tidak berbadan hukum.

2. Secara sendiri maupun bersama-sama melalui perjanjian.

Beberapa macam pelaku usaha yaitu:

a. Orang perseorangan;

b. Badan usaha;

c. Orang perseorangan dengan orang perseorangan lain:

d. Orang perseorangan dengan badan usaha;

e. Badan usaha dengan badan usaha.

3. Menyelenggarakan kegiatan usaha dalam berbagai bidang ekonomi terdapat batasan yang membedakan antara pelaku usaha dengan pelaku usaha kegiatan lain, yaitu yang dimaksud dengan pelaku 
usaha adalah mereka yang menyelenggarakan kegiatan usaha dalam berbagai bidang ekonomi.

4. Didirikan dan berkedudukan atau melakukan kegiatan dalam wilayah hukum Negara Republik Indonesia adalah orang perseorangan atau badan hukum tersebut berkedudukan atau melakukan kegiatan dalam wilayah hukum negara Republik Indonesia. Khusus badan usaha, tidak harus didirikan dan berkedudukan di wilayah Republik Indonesia.

\section{B. Tinjauan tentang Hak Asasi Manusia}

Menurut Pasal 1 Undang-Undang Nomor 39 Tahun 1999 tentang Hak Asasi Manusia (HAM) adalah seperangkat hak yang melekat pada hakikat dan keberadaan manusia sebagai makhluk Tuhan Yang Maha Esa dan merupakan anugerah-Nya yang wajib dihormati, dijunjung tinggi, dan dilindungi oleh Negara, hukum, pemerintah, dan setiap orang demi kehormatan serta perlindungan harkat dan martabat manusia. Salah satu Hak Asasi Manusia yang mendasar adalah hak atas rasa aman. Hak atas rasa aman ini tidak saja dalam pengertian fisik, psikis tetapi juga hak atas keamanan dalam kehidupan. Menciptakan kedamaian dan rasa aman, merupakan tugas bersama setiap manusia. Bagaimana menciptakan lingkungan yang damai dan tenteram, adalah sebuah kewajiban seperti menciptakan rasa aman pada orang-orang di sekitar kita.

\section{Seputaran Penyiaran Televisi Indonesia}

Televisi membawa berbagai kandungan informasi, pesan-pesan yang dalam kecepatan tinggi menyebar ke seluruh pelosok dunia. Televisi juga alat bagi berbagai kalangan untuk menyampaikan berbagai pesan untuk kalangan masyarakat. Orang dapat menyaksikan secara langsung suatu peristiwa di bagian dunia lain berkat jasa televisi. "Kehadiran televisi di dunia membawa dampak yang besar bagi umat manusia". Penyiaran melalui media televisi di Indonesia dimulai tahun 1962 bertepatan dengan dilangsungkannya Asian Games di Gelanggang Olah Raga Senayan Jakarta. Hari pertama kali menyiarkan Pesta Olahraga se-Asia IV yaitu pada tanggal 24 Agustus 1962 yang diperingati setiap tahun sebagai hari jadi TVRI.

\section{Definisi Televisi}

Televisi adalah sistem penyiaran gambar yang disertai dengan bunyi (suara) melalui kabel atau melalui angkasa dengan menggunakan 
alat yang bisa mengubah cahaya (gambar) dan bunyi (suara) menjadi gelombang listrik dan mengubahnya kembali menjadi berkas cahaya yang dapat dilihat dan bunyi yang dapat didengar

\section{Peran dan Fungsi Televisi}

Televisi merupakan alat yang digunakan sebagai sarana komunikasi searah yang sangat efektif untuk menyampaikan pesanpesan kehidupan. Televisi dianggap sebagai media pembelajaran yang efektif dan menarik, karena alat ini dapat merekam dan menangkap objek gambar hidup yang sebenarnya, dari tempat yang jauh dapat dilihat dan dinikmati oleh pemirsa seolah-olah kejadian itu berada didepan matanya. Dengan menyadari bahwa televisi menjadi sebuah alat yang sangat potensi untuk memberikan informasi dan sekaligus sebagai alat pembelajaran kepada setiap yang menikmati, maka program penyiaran dan pertunjukannya haruslah dikemas dengan berpedoman etika dan nilai-nilai budaya yang positif.

Perkembangan jaringan penyiaran lewat televisi, sejalan dengan perkembangan peradaban zaman yang begitu pesat, maka informasi dari tempat yang jauh, bahkan dari mancanegara sekalipun dalam waktu sekejap dapat dilihat dan diikuti perkembangannya. Dengan jaringan komunikasi dan informasi yang mudah dan efektif untuk penyampaian pesan, maka dunia pendidikan seharusnya juga ikut mengambil peran dalam penanganan media televisi ini sebagai pusat sumber belajar. Artinya, para perencana dan praktisi pendidikan tidak hanya sebagai penonton dari luar arena program pertelevisian indonesia. Tapi ikut ambil bagian penayangan program kependidikan yang dikemas untuk kepentingan pembinaan ahlak, moral dan nilai-nilai budaya Indonesia.

\section{Definisi Televisi Kabel}

Televisi kabel atau CATV (Community Antenna Television) adalah metode penyiaran program televisi melalui media frekuensi radio yang ditransmisikan keperangkat pelanggan dengan bantuan serat fiber optik atau kabel koaksial. Fiber mampu mendistribusikan sinyal hingga jarak $30 \mathrm{~km}$ sedangkan koaksial dalam radius beberapa ratus meter yang memerlukan amplifier sinyal.

\section{Syarat-syarat Perizinan Usaha Televisi Kabel}

Persyaratan untuk mengajukan perizinan usaha televisi kabel terdiri dari:

a. Mengisi formulir permohonan dengan dibubuhi materai Rp. 6.000;

b. Foto copy KTP Penanggung Jawab; 
c. Surat Keterangan Usaha/Domisili Perusahaan/rekomendasi dari pejabat berwenang;

d. Persetujuan Tetangga sekitar lokasi usaha mengetahui RT/RW, Lurah dan Camat;

e. Kuasa Mengurus Izin (bila pengurusan izin dikuasakan kepada pihak lain);

f. Foto Copy Kartu BPJS;

g. Izin Lingkungan atau (SPPL, UKL/UPL, Amdal);

h. Foto copy Surat Izin Usaha (SIUP dan TDP);

i. Foto copy AKTA Notaris pendirian dan perubahan bila perusahaan berbadan hukum;

j. Surat Keterangan Persetujuan Lokasi / Izin Loksi dari Pemerintah Kota Bima;

k. Foto copy IMB;

1. Izin Penyiaran dari Instansi berwenang;

m. Rekomendasi teknis (Dinas Kominfo Kota domisili);

n. Foto copy bukti kepemilikan/sertifikat tanah atau surat keterangan lain yang sah.

\section{Pengertian Sarana Fakultas Umum}

Seringkali kita mendengar istilah fasilitas sosial-fasilitas umum (fasos dan fasum) untuk menggambarkan fasilitas yang bisa digunakan publik. Dalam peraturan tentang fasilitas sosial, tak ditemukan istilah fasos dan fasum. Tapi itu adalah istilah untuk prasarana lingkungan, fasilitas umum dan fasilitas sosial yang dipendekkan menjadi fasos fasum untuk mempermudah penyebutannya. Dalam Kamus Besar Bahasa Indonesia Online yang dimaksud dengan fasilitas sosial adalah fasilitas yang disediakan oleh Pemerintah atau swasta untuk masyarakat misalnya, sekolah, klinik dan tempat ibadah. Sedangkan yang dimaksud "fasilitas umum adalah fasilitas yang disediakan untuk kepentingan umum, misalnya jalan dan alat penerangan umum".

\section{E. Pengertian Pengaturan Hukum}

Peraturan hukum secara universal adalah hal-hal yang di buat oleh suatu badan atau lembaga pemerintah yang berisi dai norma-norma di masyarakat dimana untuk mengatur tata kehidupan manusia dalam suatu negara. Hal ini memang hukum menjadi peraturan yang sulit di kaitkan 
antara pengertian dan praktiknya, sehingga kadang hakekat dari praktik lebih luas daripada hakekat dari pengertiannya begitupun sebaliknya.

\section{F. Pengertian Pertanggungjawaban Hukum}

"Pertanggungjawaban hukum berasal dari kata tanggung jawab, yang berarti keadaan wajib menanggung segala sesuatunya (kalau ada sesuatu hal, boleh dituntut, dipersalahkan, dan sebagainya)".19 Dalam Kamus hukum ada dua istilah yang menunjuk pada pertanggungjawaban, yakni Liability dan responbility. Liability merupakan istilah hukum yang luas, yang didalamnya mengandung makna bahwa liability menunjuk pada makna yang paing komprehensif meliputi hampir setiap karakter resiko atau tanggung jawab yang pasti yang bergantung, atau yang mungkin.

Selain itu liability juga merupakan kondisi tunduk kepada kewajiban secara aktual atau potensial kondisi bertanggung jawab terhadap hal-hal yang aktual atau mungkin seperti kerugian, ancaman, kejahatan biaya atau beban kondisi yang menciptakan tugas untuk melaksanakan undangundang dengan segera atau pada masa yang akan datang. Sementara itu responbility berarti hal dapat dipertanggungjawabkan atas suatu kewajiban, dan termasuk putusan, keterampilan, kemampuan, dan kecakapan. Responbility juga berarti kewajiban bertanggung jawab atas undang-undang yang dilaksanakan, dan memeperbaiki atau sebaliknya memberi ganti rugi atas kerusakan apa pun yang telah ditimbulkannya.

\section{G. Pengertian Penegakan Hukum}

Penegakan Hukum (law enforcement) mencakup kegiatan untuk melaksanakan dan menerapkan hukum serta melakukan tindakan hukum terhadap setiap pelanggaran atau penyimpangan hukum yang dilakukan oleh subjek hukum, baik melalui prosedur peradilan ataupun melalui prosedur arbitrase dan mekanisme penyelesaian sengketa lainnya (alternative desputes or conflicts resolution). Penegakan hukum adalah proses dilakukannya upaya untuk tegaknya atau berfungsinya normanorma hukum secara nyata sebagai pedoman perilaku dalam lalu lintas atau hubungan hukum dalam kehidupan bermasyarakat. Dalam menegakkan hukum, ada tiga hal yang harus diperhatikan, yaitu kepastian hukum, kemanfaatan dan keadilan. 


\section{H. Syarat-Syarat Umum Pengajuan Izin Pemanfaatan Jaringan} dari:

Persyaratan untuk mengajukan Izin Pemanfaatan Jaringan terdiri 1. Keterangan Umum:

a. Pemohon adalah pemegang izin usaha penyediaan tenaga listrik (diatur Pasal 50 ayat (4) Peraturan Pemerintah Nomor 14 Tahun 2012)

b. Pemanfaatan jaringan tenaga listrik (Diatur Pasal 50 ayat (3) Peraturan Pemerintah Nomor 14 Tahun 2012), meliputi :
a). Penyangga dan/atau jalur sepanjang jaringan listrik;
b). Serat optik pada jaringan;
c). Konduktor pada jaringan;
d). Kabel pilot pada jaringan.

2. Dasar Hukum :

a. Undang-Undang No. 30 Tahun 2009 tentang Ketenagalistrikan;

b. Undang-Undang No. 23 Tahun 2014 tentang Pemerintahan Daerah;

c. Peraturan Pemerintah No. 14 Tahun 2012 tentang Kegiatan Usaha Penyediaan Tenaga Listrik;

d. Peraturan Menteri Energi dan Sumber Daya Mineral No. 36 Tahun 2013 tentang Tata Cara Permohonan Izin Pemanfaatan Jaringan Tenaga Listrik Untuk Kepentingan Telekomunikasi, Multimedia, dan Informatika; dan

e. Peraturan Daerah Provinsi Kalimantan Timur Nomor 4 Tahun 2016 tentang Penyelenggaraan Ketenagalistrikan.

3. Persyaratan :

Persyaratan untuk mengajukan Izin Pemanfaatan Jaringan telah diatur dalam Peraturan Pemerintah Nomor 14 Tahun 2012 Pasal 50 ayat (4) yang menyebutkan bahwa persyaratan administrasi identitas pemohon ialah sebagai berikut :

a. Identitas calon pemanfaat jaringan dan surat permohonan;

b. profil calon pemanfaat jaringan;

c. Analisis kelayakan pemanfaatan jaringan;

d. Jaringan yang akan dimanfaatkan; dan

e. Rancangan perjanjian pemanfaatan jaringan.

Pengajuan Izin Pemanfaatan Jaringan tidak dikenakan biaya dan waktu penyelesaian maksimal 14 (empat belas) hari kerja sejak berkas dinyatakan lengkap dan izin berlaku selama 5 (lima) tahun dan dapat 
diperpanjang yang diatur pada diatur Pasal 12 ayat (1) Peraturan Menteri Energi dan Sumber Daya Mineral No. 36 Tahun 2013.

\section{PEMBAHASAN}

\section{A. Pengaturan Hukum Terhadap Pelaku Usaha TV Kabel Yang Mendirikan Usaha Pada Sarana Fasilitas Umum di Kota Samarinda}

Pelaku usaha wajib untuk mentaati aturan hukum dalam menjalankan usahanya tanpa terkecuali pemilik usaha TV kabel di Kota Samarinda yang saat ini, menggunakan tiang-tiang listrik yang merupakan sarana fasilitas umum aset pemerintah Kota Samarinda untuk menyalurkan siaran keseluruh masyarakat, pengguna jasa layanan TV Kabel hal mana pemasangan dan penataan jaringan perangkat milik operator TV Kabel menggunakan tiang listrik tersebut mengganggu estetika keindahan Kota Samarinda. Pemerintah menyediakan fasilitas dan prasarana umum dengan tujuan mendorong peningkatan kegiatan ekonomi masyarakat, meningkatkan pendapatan dan retribusi, dan memudahkan perdagangan antar Negara.

Pemerintah sebagai pemegang otoritas untuk mengatur rakyatnya memiliki andil guna menciptakan stabilitasi diberbagai bidang baik dalam ekonomi, sosial juga bagi warga negaranya. Disamping itu pemerintah juga berperan sebagai fasilitator dan tetap memberikan kebebasan atas hak pribadi untuk mengembangkan bisnis. Fasilitas yang utama ialah berupa infrastruktur baik berupa tempat transit bisnis maupun fasilitas kemudahan dalam proses perijinan bisnis.

Adanya ketersediaan infrastuktur yang memadai dari berbagai bidang seperti industry, perdagangan jasa dan pertanian dapat membuat para pekerja dapat mengeksplor dirinya lebih jauh dan berkualitas. Perlunya melatih kualitas dan kreatifitas diri sebagai dasar menghasilkan sesuatu yang bernilai. Sehingga, akan mempengaruhi hidup manusia terutama pada masalah perekonomian. Memiliki keterampilan dengan ketersediaan infrastruktur yang memadai dapat meningkatkan pendapatan suatu masyarakat, peningkatan lapangan kerja, dan pemerataan pendapatan.

Pemasangan dan penataan jaringan TV Kabel di Kota Samarinda dinilai semerawut dan tidak tertib karena banyak yang menumpang ditiang listrik. Sementara itu penindakan hukum terhadap pelaku usaha TV Kabel tersebut saat ini Pemerintah Kota Samarinda belum memiliki Peraturan 
Daerah yang secara spesifik mengatur tentang perizinan usaha TV Kabel di Kota Samarinda. Aktifitas pelaku usaha TV Kabel yang menggunakan tiang-tiang listrik yang menjadi sarana fasilitas umum di Kota Samarinda tanpa izin penyiaran maupun izin pemanfaatan jaringan bahkan pemasangan kabel tidak sesuai dengan standar instalasi, keamanan dan keselamatan serta kelestarian fungsi lingkungan sehingga aktifitas pelaku usaha TV kabel bertentangan dengan Peraturan Menteri Energi dan Sumber Daya Mineral Republik Indonesia Nomor 36 Tahun 2013 tentang Tata Cara Permohonan Izin Pemanfaatan Jaringan Tenaga Listrik Untuk Kepentingan Telekomunikasi, Multimedia dan Informatika Pasal 3 ayat (4) yang menyebutkan bahwa "Pemanfaatan Jaringan sebagaimana dimaksud pada ayat (1), ayat (2), dan ayat (3) dapat dilakukan setelah memperoleh IPJ Telematika dari Menteri”. Serta bertentangan dengan asas yang terdapat pada Peraturan Daerah Provinsi Kalimantan Timur Nomor 4 Tahun 2016 tentang Penyelenggaraan Ketenagalistrikan Pasal 2 yang menyebutkan bahwa "Penyelenggaraan ketenagalistrikan berdasarkan asas manfaat, efisiensi berkeadilan, berkelanjutan, berkesinambungan, optimalisasi ekonomi, pemanfaatan sumber daya energi, mengandalkan pada kemampuan sendiri, kaidah usaha yang sehat, keamananm keselamatan, kelestarian fungsi lingkungan, dan otonomi daerah.

Berdasarkan Peraturan Menteri Energi dan Sumber Daya Mineral Republik Indonesia Nomor 36 Tahun 2013 tentang Tata Cara Permohonan Izin Pemanfaatan Jaringan Tenaga Listrik Untuk Kepentingan Telekomunikasi, Multimedia dan Informatika Pasal 3 ayat (3) huruf a menyebutkan bahwa :

"Pemanfaatan jaringan sebagaimana dimaksud pada ayat (1) dilakukan apabila tidak mempengaruhi kelangsungan penyediaan tenaga listrik, dengan ketentuan sebagai berikut : a) Untuk pemanfaatan Penyangga dan atau jalur sepanjang jaringan sebagaimana yang dimaksud pada ayat (2) huruf a dilakukan dengan mempertimbangkan : 1) Ketersediaan kapasitas jaringan yang masih dapat dimanfaatkan; dan 2) Kekuatan konstruksi penyangga".

Izin Pemanfaatan Jaringan memiliki tenggat waktu jika masa berlakunya telah habis maka pelaku usaha TV Kabel wajib untuk memperpanjang kembali izin tersebut sebagaimana ketentuan Peraturan Menteri Energi dan Sumber Daya Mineral Republik Indonesia Nomor 36 
Tahun 2013 tentang Tata Cara Permohonan Izin Pemanfaatan Jaringan Tenaga Listrik Untuk Kepentingan Telekomunikasi, Multimedia dan Informatika Pasal 12 ayat (1) yaitu, masa berlaku Izin Pemanfaatan Jaringan ialah 5 (lima) tahun. Ayat (2) pemegang Izin Pemanfaatan Jaringan wajib memperbaharui Izin paling lambat 3 (tiga) bulan sebelum masa berlakunya berakhir. Serta, pada ayat (3) Permohonan perpanjangan Izin Pemanfaatan Jaringan harus memenuhi persyaratan dan mengikuti tata cara permohonan.

Sanksi Administrasi dapat diterapkan kepada pelaku usaha TV Kabel di Kota Samarinda jika terbukti tidak memiliki Izin Pemanfaatan Jaringan Telematika namun masih beroperasi. Undang-Undang No. 30 Tahun 2009 tentang Ketenagalistrikan Pasal 48 Ayat (1) menyebutkan bahwa: "Setiap orang yang melanggar ketentuan sebagaimana dimaksud dalam Pasal 16 ayat (3), Pasal 17 ayat (3), Pasal 27 ayat (2), Pasal 28, Pasal 33 ayat (3), Pasal 35, Pasal 37, Pasal 42, atau Pasal 45 ayat (3) dikenai sanksi administratif berupa: a. teguran tertulis; b. pembekuan kegiatan sementara; dan/atau c. pencabutan izin usaha". "Ayat (2) Sanksi administratif sebagaimana dimaksud pada ayat (1) ditetapkan oleh Menteri, gubernur, atau bupati/walikota sesuai dengan kewenangannya".

Tahun 2017 telah dicabutnya regulasi tentang pengaturan Izin Gangguan, salah satunya ialah izin pemanfaatan sarana fasilitas umum yang dinilai menjadi penghambat dunia usaha maupun investasi di Indonesia maka dari itu Pemerintah memberikan wewenang kepada pihak PT. PLN (Persero) untuk tetap mengawasi serta menjaga keamanan dan keselamatan yang berdasarkan Peraturan Daerah Provinsi Kalimantan Timur Nomor 4 Tahun 2016 tentang Penyelenggaraan Ketenagalistrikan. Pengawasan inilah menjadi tugas PT. PLN (Persero) sebagai Badan Usaha Milik Negara yang telah disebutkan dalam pasal 1 ayat (50) Peraturan Daerah Provinsi Kalimantan Timur Nomor 4 Tahun 2016 tentang Penyelenggaraan Ketenagalistrikan bahwa "Pengawasan adalah segala usaha dan kegiatan yang dilakukan untuk menjamin keamanan lingkungan dan tegaknya peraturan perundang-undangan ketenagalistrikan.

\section{B. Pertanggungjawaban Pelaku Usaha TV Kabel Yang Mendirikan Usaha Pada Sarana Fasilitas Umum di Kota Samarinda Terhadap Pemerintah Kota Samarinda Jika Terjadi Insiden Yang Merugikan}


Setiap penanggung jawab usaha dan/atau kegiatan (perusahaan/ badan hukum) yang mengakibatkan pencemaran dan/atau kerusakan lingkungan dianggap sebagai perbuatan melawan hukum. Penanggung jawab usaha dan/atau kegiatan tersebut memiliki tanggung jawab untuk mengganti kerugian yang ditimbulkan, sejauh terbukti telah melakukan perbuatan pencemaran dan/atau perusakan. Pembuktian tersebut baik itu nyata adanya hubungan kausal antara kesalahan dengan kerugian (liability based on faults) maupun tanpa perlu pembuktian unsur kesalahan (liability without faults/strict liability). Saat ini terdapat 2 pertanggung jawaban Pelaku Usaha TV Kabel Yang Mendirikan Usaha Pada Sarana Fasilitas Umum di Kota Samarinda, yaitu :

\section{Pertanggungjawaban Administrasi}

Setiap tindakan hukum itu mengandung makna penggunaan kewenangan maka didalamnya tersirat adanya kewajiban pertanggungjawaban. Kewenangan pemerintahan tersebut berkaitan dengan adanya pejabat atau badan pemerintahan yang bertanggung jawab, baik berupa pengawasan maupun pemberian sanksi. Cara- cara pengawasan dalam penyelenggaraan pemerintahan dapat ditinjau dari dari segi kedudukan badan atau organ yang melaksanakan pengawasan, baik dari luar maupun dari dalam. Kemudian ditinjau dari segi saat atau waktu dilaksanakannya pengawasan preventif dan pengawasan refresif. Dan yang terakhir di tinjau pengawasan dari segi Hukum.

Penegakan hukum administrasi yang dikenakan terhadap pelanggaran-pelanggaran tersebut dimaksudkan sebagai sarana untuk mengubah perilaku. Tujuan utama penegakan hukum administrasi adalah bagaimana agar perilaku yang dapat dipandang sebagai pelanggaran tidak terjadi lagi. Terutama yang diharapkan dengan pengenaan sanksi administrasi adalah bukan semata-mata untuk memberikan beban kepada pelakunya, melainkan merubah perilakunya. Kalau pelanggaran-pelanggaran tersebut tidak lagi terjadi di masa-masa selanjutnya maka diharapkan munculnya sumbangan positif bagi pemenuhan kewajiban perizinan. Sekaligus di situ ada semacam pendidikan hukum, yaitu agar masyarakat lebih berhati-hati dan bersungguh-sungguh dalam memenuhi kewajiban.

Umumnya macam-macam dan jenis sanksi dicantumkan dan ditentukan secara tegas dalam peraturan perundang-undangan bidang administrasi tertentu. Secara umum dikenal beberapa macam sanksi dalam hukum administrasi, yang pertama Paksaan pemerintah 
bestuursdwang kemudian yang kedua Penarikan kembali keputusan yang menguntungkan yaitu izin, subsidi, pembayaran, dan sebagainya. Setelah itu yang ketiga Pengenaan uang paksa oleh pemerintah dwangsom dan terakhir yang keempat Pengenaan denda administratif administratieve boete.

Berkaitan dengan perilaku hal tersebut, semestinya pihak TV Kabel dalam hal ini hanya dapat dikenakan sanksi administratif saja sebagaimana tercantum pada Undang-Undang Nomor 30 Tahun 2009 tentang Ketenagalistrikan Pasal 48 Ayat (1). Kepastian ganti rugi atau relokasi fasilitas sosial (fasos) dan fasilitas umum (fasum) sampai dengan saat ini belum jelas. Pada kenyataannya yang dirugikan ialah pemerintah kota Samarinda serta masyarakat apabila terjadi kerusakan jika terjadi insiden. Menurut keterangan pihak perusahaan TV, bahwa mereka pernah menyurati pihak yang berwenang terkait hal perizinan tersebut pemerintah kota Samarinda, namun belum ada tindak lanjut konkrit yang dilakukan atas hal pemakaian fasilitas umum dengan tujuan komersil.

\section{Pertanggungjawaban Hukum Secara Perdata}

Pengertian secara mendasar Hukum perdata mengatur hak dan kewajiban orang-orang yang mengadakan hubungan hukum. Semua peraturan hukum yang mengatur hak dan kewajiban orang perseorangan atau badan hukum dalam suatu hubungan hukum disebut dengan hukum perdata civil law. Karena hukum perdata mengatur substansi hak dan kewajiban pihak-pihak dalam hubungan hukum antara orang yang satu dan orang yang lain, disebut juga hukum perdata materiil substantive civil law. Pada perkara perdata, tugas pengadilan adalah mencari kebenaran sesungguhnya dari apa yang dikemukakan dan dituntut oleh pihak-pihak. pengadilan tidak boleh melebihi dari itu. Apabila tergugat telah mengakui kebenaran tuntutan penggugat, perkara menjadi selesai.

Pasal 1365 Kitab Undang-Undang Hukum Perdata, maka yang dimaksud dengan perbuatan melanggar hukum adalah perbuatan yang melawan hukum yang dilakukan oleh seseorang yang karena salahnya telah menimbulkan kerugian bagi orang lain. Dalam ilmu hukum dikenal 3 (tiga) kategori dari perbuatan melawan hukum, yaitu sebagai berikut :

1) Perbuatan melawan hukum karena kesengajaan;

2) Perbuatan melawan hukum tanpa kesalahan (tanpa unsur kesengajaan maupun kelalaian); 
3) Perbuatan melawan hukum karena kelalaian.

Maka model tanggung jawab hukum adalah sebagai berikut:

1) Tanggung jawab dengan unsur kesalahan (kesengajaan dan kelalaian) sebagaimana terdapat dalam pasal 1365 Kitab UndangUndang Hukum Perdata.

Berbunyi "Tiap perbuatan yang melanggar hukum dan membawa kerugian kepada orang lain, mewajibkan orang yang menimbulkan kerugian itu karena kesalahannya untuk menggantikan kerugian tersebut".

2) Tanggung jawab dengan unsur kesalahan khususnya kelalaian sebagaimana terdapat dalam pasal 1366 Kitab Undang-Undang Hukum Perdata; Berbunyi "Setiap orang bertanggung jawab, bukan hanya atas kerugian yang disebabkan perbuatan-perbuatan, melainkan juga atas kerugian yang disebabkan kelalaian atau kesembronoannya".

3) Tanggung jawab mutlak (tanpa kesalahan) sebagaimana terdapat dalam Pasal 1367 Kitab Undang-Undang Hukum Perdata. Berbunyi "Seseorang tidak hanya bertanggung jawab atas kerugian yang disebabkan perbuatannya sendiri, melainkan juga atas kerugian yang disebabkan perbuatan-perbuatan orang-orang yang menjadi tanggungannya atau disebabkan barang-barang yang berada di bawah pengawasannya.

Terkait dengan hubungan keperdataan antara TV kabel Konvensional dengan pihak pemerintah kota tidak terjadi hal yang keliru di depan hukum, karena di dalam hukum perdata mengenal dengan istilah syarat sah nya suatu perjanjian yang mempunyai akibat hukum yaitu wanprestasi. Disamping itu pola cedera hukum yang lain adalah perbuatan melawan hukum. TV kabel di Kota Samarinda telah sengaja menggunakan fasilitas yang diperuntukkan bagi masyarakat umum dan pihak TV kabel menggunakan fasilitas umum tersebut guna kepentingan komersil semata.

\section{PENUTUP}

\section{A. Kesimpulan}

1. Pengaturan hukum bagi pelaku usaha yang mendirikan usaha TV Kabel di fasilitas sarana umum di Kota Samarinda terdapat pada UndangUndang No. 30 Tahun 2009 tentang Ketenagalistrikan Pasal 48 Ayat (1) 
2. Pertanggung jawaban hukum pelaku usaha TV Kabel yang mendirikan usaha pada sarana fasilitas umum di kota Samarinda terhadap pemerintah kota Samarinda jika terjadi insiden merugikan yang mengakibatkan pencemaran dan/atau kerusakan lingkungan dianggap sebagai perbuatan melawan hukum. Penanggung jawab usaha dan/atau kegiatan tersebut memiliki tanggung jawab untuk mengganti kerugian yang ditimbulkan, sejauh terbukti telah melakukan perbuatan pencemaran dan/atau perusakan yaitu pertanggung jawaban secara administratif dan pertanggung jawaban secara hukum perdata. Sejauh pelaku usaha TV Kabel memenuhi 3 (tiga) kategori melawan hukum, maka dapat dipertanggung jawabkan secara hukum perdata.

\section{B. Saran}

1. Sebaiknya Pemerintah Daerah Kota Samarinda harus membuat peraturan daerah yang secara spesifik mengatur tentang pengawasan terhadap perizinan usaha TV Kabel di Kota Samarinda karena dengan adanya peraturan daerah tersebut diharapkan dapat meminimalisir jumlah pelanggaran hukum.

2. Sebaiknya pelaku usaha TV Kabel sudah tidak menggunakan tiang penyangga jaringan listrik yang merupakan sarana fasilitas umum milik pemerintah kota, jauh lebih baik apabila kabel pada pelaku usaha TV Kabel ditanam pada permukaan tanah, agar meminimalisir adanya konsleting listrik, kebakaran akibat arus pendek listrik dan tidak mengganggu estetika kota.

\section{DAFTAR PUSTAKA}

\section{Buku :}

Abdulkadir Muhammad, 2010, Hukum Perusahaan Indonesia, Citra Aditya Bakti, Bandung.

Badruddin dan Roif, 2005, "Media Massa, Benarkah Sumber Informasi?". IAIB Press, Serang.

DEPDIKNAS, 2003, Kamus Besar Bahasa Indonesia, Balai Pustaka, Jakarta. 
Ishadi, 1997,Bisnis Televisi di Tengah Persaingan Antar Media, Cet I, PT.Remaja Rosdakarya, Bandung.

Leden Marpaung, 1999, Menggapai Tertib Hukum Di Indonesia, Cet I,

Penerbit Sinar Grafika, Jakarta.

Milton Chen, 1996, Anak-Anak dan Televisi : Buku Panduan Orang Tua

Mendampingi Anak-Anak Menonton Televisi, PT. Gramedia Pustaka Utama, Jakarta.

Munir Fuady, 2005, Pengantar Hukum Bisnis Menata Bisnis Modern di Era Global, Cet IV, Penerbit PT. Citra Aditya Bakti, Bandung.

Nasir Tamara,1997, Industri Televisi dan Dampak Kebudayaan: Bercinta dengan Televisi, Cet I, PT. Remaja Rosdakarya, Bandung.

Onong Ochjana Effendy, 1984, Televisi Siaran: Teori dan Praktek, Alumni, Bandung.

Peter Mahmud Marzuki, 2005, Penelitian Hukum, Kencana, Jakarta.

Sunaryati Hartono, Penelitian Hukum di Indonesia pada akhir abad 20, Alumni, Bandung.

Suparman Usman, 2008, Etika dan Tanggung Jawab Profesi Hukum di Indonesia, Gaya Media Pratama, Tanggerang.

Soerjono Soekanto, 2008, Faktor-Faktor yang Mempengaruhi Penegakan Hukum, PT. Raja Grafindo Persada, Jakarta.

Tiur LH Simanjuntak, 1993, Dasar-Dasar Telekomunikasi, Cet I, Alumni, Bandung.

\section{Peraturan Perundang-undangan :}

Pasal 1 Undang-Undang Nomor 39 Tahun 1999 tentang Hak Asasi Manusia (HAM).

Pasal 1365 Kitab Undang-Undang Hukum Perdata.

Pasal 1367 Kitab Undang-Undang Hukum Perdata.

Peraturan Pemerintah No. 14 Tahun 2012 tentang Kegiatan Usaha Penyediaan Tenaga Listrik. 
Peraturan Menteri Energi dan Sumber Daya Mineral No. 36 Tahun 2013 tentang Tata Cara Permohonan Izin Pemanfaatan Jaringan Tenaga Listrik Untuk Kepentingan Telekomunikasi, Multimedia, dan Informatika.

Peraturan Daerah Provinsi Kalimantan Timur Nomor 4 Tahun 2016 tentang Penyelenggaraan Ketenagalistrikan.

Undang-Undang Republik Indonesia Nomor 28 Tahun 2009 Tentang Pajak Daerah dan Retribusi Daerah.

Undang-undang Nomor 8 Tahun 1999 dan Pasal 1 butir 3 Tentang Pelaku Usaha.

Undang Undang No. 8 Tahun 1999 tentang Perlindungan Konsumen.

Undang-Undang No. 30 Tahun 2009 tentang Ketenagalistrikan.

Undang-Undang No. 23 Tahun 2014 tentang Pemerintahan Daerah. 